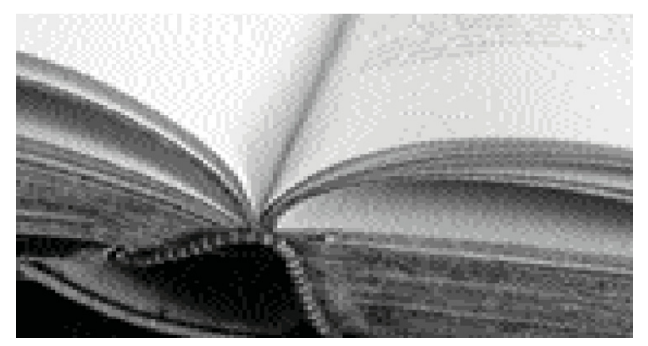

\title{
The Golden Passport. Harvard Business School, the Limits of Capitalism, and the Moral Failure of the MBA Elite
}

\author{
de Duff McDonald \\ Harper Collins, New York, 2017, 672 pages
}

Duff McDonald's previous books include Last Man Standing: The Ascent of Jamie Dimon and JPMorgan Chase (2009) and The Firm: The Story of McKinsey and Its Secret Influence on American Business (2014). Clearly he is no stranger to the workings or woes of the US financial community. His new book: The Golden Passport: Harvard Business School, the Limits of Capitalism, and the Moral Failure of the MBA Elite, shines further light into the shadows of American capitalism and the education of its architects and builders. It stands on a huge research project, journalistic rather than academic. It names names and facts rather than theories. It complements those who fire cheap shots at the financial community without knowing much about how it works or its key players. Indeed, prior to 2008, most of us were only dimly aware how our collective well-being hinged on the financial community's continued functioning. All of which validates McDonald's continued inquiry into the causes and context of the business-driven inequities showcased in Piketty's work. Cui bono? Who benefits from the Harvard Business School (HBS) in particular, or from management education in general?

\section{I - Book One}

The Golden Passport (TGP) packs three separable works into its 659 pages. Book One appeals to the scandal-mongers, an anti-HBS 
tract in the finest muck-raking tradition; though some might feel McDonald goes overboard. When HBS opened in 1908, McDonald argues, its declared purpose was to produce exemplary and enlightened managers able to balance private profitmaking against public benefit. It would be a university-based project to transform business management into a self-aware, skilled, profession - globally respected. It would pioneer an ethical and socially oriented professional cadre that could stand proudly alongside the professionals in medicine and engineering. McDonald's charge against HBS is of gross hypocrisy, that its noblesounding intent has been corrupted by institutional narcissism, opportunistic corner-cutting, and flabby intellectualizing, but mostly by boundless greed - the very antithesis of the 'leadership' the school claims to teach. Plus, the academic dimension of HBS's project, to build a professionsupporting 'science of business', has failed, dragging the university to abandon, if not trample on, its pedagogical responsibilities to its students. Today it is not clear what HBS does for its students or for the management education industry that it helped shape for generations. Its high-flown rhetoric masks unacknowledged failure and rampant self-serving as many of its faculty members gorge on the school's reputation, connections and wealth, and divert their energies into high-fee consulting work. Specifically, McDonald claims Michael Jensen's arrival in 1985 helped institutionalize an ideology of 'maximizing shareholder value' (MSV) over all other objectives. MSV propagated rapidly through the financial community and almost certainly played a part in the 2008 financial crisis.
Two facts glare out from the trove of data; Michael Porter blithely consulting for Gaddafi's murderous regime and Jeff Skilling's treasonous Enron. Bad apples? No question some HBS graduates are less than socially oriented, but surely all are superbly trained in the skills to manage? Curiously little of the thousands of hours of business school "research" or the millions of lines of 'findings' in the academic journals, examines business schools' own activities or justification for existing. Their impact on HBS's students is not measured in the ways researchers in schools of education regularly evaluate schooling. Some business professors suggest the HBS selection process is so rigorous that getting in is proof the student is a "leader", and that the subsequent "educational experience" need go little beyond connecting to the HBS-cultivated routes to plum jobs, with corporate recruiters handily feeding in HBS's dining halls. Placement, networking, and recruitment are major parts of the HBS experience.

Against HBS's lofty claims TGP summarizes under-noted research by Henry Mintzberg and Joe Lampel, published in Fortune in 2001 but subsequently ignored. In the style of In Search of Excellence, the bestselling business book of all time, they looked at the careers of nineteen exemplary HBS graduates who, per Harvard Business Review's managing editor David Ewing in 1990, "made it to the top". Of the nineteen, ten clearly failed as "leaders", only five succeeded. Earlier, Harvard President Derek Bok made critical comments about HBS and its MBA curriculum in his 1978 annual report; the absence of ethics courses and inattention to corporate social responsibility, not-for-profit organizations, and the 
public sector. Bok also noted the lack of academic justification for HBS's holiest practice - the case method. The school's response, orchestrated by a task force of exHBS CEOs and McKinsey-employees was titled "The Success of a Strategy". It was defensive and dismissive, ironically endorsing Bok's comments, an inept display of crisis-management. Likewise, HBS refused to assist McDonald with his research. Book One, then, is a rollicking ride that HBS's naysayers will love and its graduates and apologists will probably try to dismiss.

\section{II - Book Two}

This is a lengthy and detailed history of HBS, its origins and many-phased evolution into today's globally recognized educational institution. These details are not everyone's bed-time reading and TGP in print is probably too heavy to travel with. But no one writing about HBS and its impact on the now global management education industry can afford to ignore it. While the muckraking Book One weaves in and out of Book Two's robust and original history, one central message is how American HBS is - to be contrasted against LSE, the Hautes Écoles, and the other European business schools. While the latter were mostly created, shaped, and sometimes funded by national policies, HBS is private and struggled into existence ("a delicate experiment") through inevitable thickets of university politics, private fundraising, elite arm-twisting, and political influence. Institutions must weather their changing circumstances but commentators seldom get into the specifics and results. Yet this is crucial to understanding HBS, its student body, its curriculum, its use of cases, its campus layout and location across the
Charles River from Harvard's main campus, its superlative Baker Library, its huge embedded book, magazine, and case publishing businesses, its 'executive education' offerings, its part in World War II, and its deep penetration into American political life as well as its obvious impact on the Wall Street community. While TGP reflects some aspects of Rakesh Khurana's fine history of the US business school, From Higher Aims to Hired Hands (2007), it reveals more about HBS. Such stories are important to historians, but they also reveal what many commentators ignore, that business schools are heterogeneous in their origins, histories, self-images, and impacts. Summarizing them as a genus in pieces such as "Have Business Schools Lost their Way?" or "The End of Business Schools? Less Success than Meets the Eye", obscures rather than clarifies what they are and do, and how they impact the world - or do not.

TGP opens with Casey Gerald, the 2014 Valedictorian, giving "the most stirring speech ever by an MBA". He wound up with an appeal to his 900+ graduating classmates that captured HBS's initial aim to "educate leaders who make a difference in the world". "In your hands, as well as mine, lies the hope for a new generation of business leader". He spoke of 'the hard, frightening, and unending work of pulling new dreams, hopes and possibilities from the darkness'. The speech went viral. Paraphrasing James Baldwin, Gerald later told McDonald he loves HBS and for that reason has "the right to criticize her perpetually". "What HBS does well is train people to figure out what to do in situations of uncertainty, imperfect information, and tight deadlines". But, pointing at HBS alum Robert S. McNamara, he added "the tragedy of HBS is that you can 
use that ability to build a great company or destroy the planet". From the get-go McDonald raises the bedeviling question of Harvard's responsibility to its students - or that of any university that hosts a business school. Is the business school a "trade school" teaching proven managerial methods for minimizing waste or maximizing efficiency and ROI, or is its higher purpose to nurture the students' moral and ethical thinking, the Newmanesque project to help them find themselves and their place in a world of uncertainty, imperfect information, and complex pressures?

\section{III - Book Three}

Which gets us to Book Three, again woven into TGP rather than made explicit. This book considers management education as a global phenomenon, arguably the most important thing to happen to higher education in the last century. At the same time, management education looms ever larger for all students, the elephant-in-the-room of their career planning (and financing) - to BSchool or not to B-School? Again, America leads the way with around one in five university students "studying" some form of business course. There are huge national and international resource and culture management issues here. The subtext of Books One and Two is questions about business schools' claims to "educate" in any meaningful sense. Acquiring the technical capacity to "run the numbers' or even to draw conclusions from the 500 cases covered during the HBS MBA program, is probably not what Humboldt or Newman meant by 'an education'. The self-regarding hubris of Gerald's speech is stunning and McDonald reveals the typical HBS students' sense of privilege.
Yet Gerald's mention of "tragedy" hinges on recognizing the differences between technical up-skilling and 'education'. This remains the core question for the management education industry, much evident in its current critiques and breast-beating - and it goes back to its origins. If a business school fails to provide 'an education' even when housed within a respectable, even elite, university, how come? HBS's founding was not management education's origin, but it was hugely influential, at least until the 1980s when neoliberal ideology and quantitative methods became dominant. Ultimately TGP is remarkable because the questions McDonald probes in Book Three are less "What should business schools do now?" on which there is a vast unhelpful literature than "How did successive HBS administrations manage to avoid addressing Gerald's question?" How did an elite institution like HBS, with the best resources and reasons to stick to high educational aspirations, come to slide into hypocrisy and opportunistic money-grubbing?

McDonald arranges TPG into 61 episodes, each with its own historical detail but, more to the point, sense of direction. This structure lets him dispense with the broad generalities that mark the bulk of the literature on business schools and management education. Rather, it lets McDonald explore HBS's evolution as the blow-by-blow interplay of entrepreneurial vision and situational constraint, implicitly evaluating the leadership of the day according to its courage, pusillanimity, blindness, ambition, or even deceitfulness. This is crucial because just as McDonald and Khurana both presume business schools' original virtue, the "higher aims" of Khurana's title, McDonald identifies an original sin - the absence of a core 
notion of what private sector business is actually about, what firms are or are for. At the end of the nineteenth century the private firm's 'right to exist, operate, and make profits' was taken for granted in the US; a view not equally shared in Europe. By the end of the twentieth century such rights were being contested in both regions, and elsewhere. What is a firm? Are firms people? Do firms have social obligations? With the US Supreme Court's 2010 Citizens United vs FEC decision the US firm's right to exist was both reaffirmed and further extended to being able to vote. Yet the puzzle remains, memorialized by Ronald Coase's Nobelwinning 1937 paper questioning the nature of the private firm. Solving this puzzle, establishing what "the firm" is, would close the gap between instrumentality and responsibility, between a business's private and public objectives, and thereby address Gerald's question. It would also provide a metric for management education performance that would finish off the journalistic rankings' impact on student recruitment and business school administration. Just as educators bewail "teaching to the test", so business schools are increasingly "managing to the rankings".

\section{IV - To TGP's Core Material}

Many remarkable people appear during TGP's 61 episodes; including Frederick Taylor, Wallace Donham, Elton Mayo, Georges Doriot, Donald David, Alfred Chandler, Kenneth Andrews, Derek Bok, Marvin Bower, John McArthur, and Michael Porter - and, of course, George W. Bush, Robert S. McNamara, Jeff Skilling, and Michael Jensen. Not all these names are familiar. Taylor's early involvement was arranged by Edwin Gay, the school's first Dean, who also brought in the case method. Scientific Management endorsed the idea of a science of business, but more correctly began the history of failing to find it. Donham was probably the most influential of all HBS deans and his legacy has yet to be fully understood. As a lawyer and banker, he promoted the study of business managers' ethics, helping establish the discipline of "business ethics" that has marked HBS ever since, albeit overshadowed today. Donham's connections extended into Washington and government, leading HBS into a supreme place in national politics. He was also a hugely effective fund-raiser. He brought the Baker gift to fruition - enabling HBS's present campus and the Baker Library. That success may have baked in HBS's pursuit of a massive endowment (at around $\$ 4$ billion, more than double Stanford's, the next in size), and to pressure its alums unremittingly to "give back". Georges Doriot was a major curriculum innovator, but also helped invent today's "venture capital" industry and the economic phenomenon of "Silicon Valley". He also helped found INSEAD. Derek Bok, twice appointed President of Harvard, continues to draw attention to the damage corporatization has wrought in universities. Michael Porter is perhaps HBS's last "superstar". He moved gracefully and strategically from academic economics to consulting to corporations and to advising governments. He now offers them guidance on how to organize, inter alia, their nations' health-care and social welfare.

TGP contains a great deal of quantitative data, seldom boring, but McDonald's analysis is focused more on the people who made a difference to HBS - if not to the larger world. They ensured HBS would not be 
tripped up by the lack of a viable "theory of the private firm" and shown to be "without academic clothes". Episode 42 - The Murder of Managerialism - is among the most interesting and pivotal. The period is 1980 . McDonald sets it up as a conflict between traditionalists who, aware of the post-Reagan politics and decline of government regulation, believed US managerial capitalism and the MBA program needed a little "adjusting" versus, in an opposing camp, economist radicals who made a new case for treating US firms' managers as the source of the nation's woes. Instead of lauding insightful, worldly wise, and socially conscious "general managers" of previous episodes, these radicals argued managers often stood in the way of "market forces" whose unfettered activity would maximize economic efficiency. McDonald notes the activities of the conglomerates who explored every loophole and pushed every boundary with "innovative business models".

But the radicals were also profoundly supported by academic work at the Chicago School of Economics, further endorsed by the Nobel Committee's unrestrained appetite for their neoliberal economics. Friedman's free-market argument that the managers' role was to maximize shareholder return was significantly extended by the principal-agent theorizing of Jensen \& Meckling (1976). "Investor capitalism" resulted, its politics denied. Henceforth the manager's incentives were to be fully aligned with the shareholders', pushing aside previous incentives to "empire build", or preserve employment, or to maximize market share or "strategic advantage". What is the point of increased market share or "sustained competitive advantage" if it does not increase profits? Executive pay excesses soon followed, given CEOs could reward themselves handsomely for imaginative use of the investors' funds. All of which reflected dissolving social norms and regulations and the rapid shift to a more 'business friendly' national and international politics. McDonald quotes Khurana's pithy comment that "A kind of market fundamentalism took hold in business education." Even though minimizing taxes by off-shoring profits and "corporate inversions' had yet to be perfected, the last traces of the New Deal were being scrubbed from American capitalism.

Adjusting to these new times Dean McArthur brought Jensen to HBS in 1985 (full time in 1989) to put a theoretical imprimatur on the new thinking being advanced. McDonald cites some of the vast literature these changes generated. Pushing back, within the university community there is rising anxiety about the business school's role. Should HBS argue, as Bok suggested, that business managers have social responsibilities to 'stakeholders' beyond the investors, to the employees, tax-gatherers, neighbors, communities, and even Mother Nature perhaps? Is the school's role to serve only shareholders (and those CEOs completely in their pocket) or to be more activist, to argue against corporations' espoused narrow interests? Why would its graduates then be hired?

Obviously, these puzzles cannot be addressed, nor management education's proper or reasonable objectives established, nor its performance measured, without a managerially-relevant "theory of the private firm" or "science of business". This has yet to be generated. Of course, there are many theories of the firm, such as the supply and demand scissors of neoclassical economics, or the 
bureaucracies studied by "organization theorists", or the networks of advice and influence studied by cultural theorists. But none seems adequate to illuminate the practical complexities of the managerial task - pluralistic, many dimensioned, politically embedded in a mixed economy, ethically and morally burdened because people's lives are being shaped, and increasingly technologically contingent. Contrary to most academic writing that pursues simplicity and rigor as "the right path" towards better theory, managers confront the holistic contingent nature of their activity. They produce profits not theories or even political justifications for their firms.

This sought-after new model or thinking might come from the business school community, though it has remarkably little to show for more than a century of trying. There is not much exemplary work that both influences management thinking and lies outside mainstream economics; principal exceptions being Burns \& Stalker (1961), Chandler (1960), and Porter (1980). The most recent excitements are transaction costs or behavioral economics, yet neither has attracted interest from working managers. New theory might come from one of the university's other faculties, education, politics, or psychology perhaps. Big data and artificial intelligence is showing the result of decades of substantial investments in computing perhaps live managers will no longer be needed. Or new theory might emerge from historical studies, as Chandler's did. Even as most business schools pay little attention to history, HBS sustains an active business history department. Episode 27 deals with this department's establishment and history. Its revelation of Harvard's gender bias is remarkable. Beyond Chandler's massive contribution that, inter-alia, established the field of corporate strategy, this department's impact has been limited. McDonald pays further attention to HBS's struggles with gender-bias, especially the current dean Nohria's claims to have addressed them (in Episode 61).

But to return to management education's core problem. Absent a viable manageriallyapplicable theory of the private firm that can be used as a touchstone for evaluating the managers' or teachers' analyses, what values and quality metrics are actually in play in business schools like HBS? The facts; the intellectual vacuum at the center of the business school curriculum has been filled by the faculty members' own projects - constructions as varied as agentbased models, principal-agent theory, models of market risk and uncertainty, and so on. These are all fine and researchable, and eminently publishable in journals managers do not read, so serving only the academics' careers. They do little to illuminate managers' work. Additional fact: most management professors have limited managerial experience and are not well equipped to enter the manager's world even if they chose to understand it. The possibilities of publishing research about managerial work are limited. Likewise, there is limited opportunity to research and publish about their own work as teachers, though an important exception is Academy of Management Learning and Education.

\section{V - To "Business Ethics"}

The lack of a managerially-informing theory of the private firm implies deep questions about HBS's claim to research or 
teach "business ethics". McDonald is outraged at HBS's hypocrisy; perhaps overly so. But his righteous outrage is the source of the energy behind TGP, as it drove his earlier books. It is quite one thing for a bank or a consulting firm to be less than squeaky-clean, quite another when ethical laxity arises within an elite university, when efforts are made to hide rather than correct it. HBS claims to teach business ethics yet tilts the MBA experience towards narrow analytic thinking and to treating the firm's money as its managers' most significant product. HBS's own profit seeking contradicts its declared ideological position.

Given the professoriate's unfamiliarity with managerial work, or even being managed, they can scarcely claim to bring much ethical wisdom into the case-room. The suggestion that consulting, advising without bearing managerial responsibility, can help professors experience ethical issues is an insult to managers. Teaching ethics based on theory is even trickier. Without a theory of the firm 'business ethics' cannot be separated from the age-old study of ethics in general. What is it about business that makes adding "business" to "ethics" a meaningful label? Is it no more that the challenge to behave ethically within the context of business life? Does being engaged in business, especially in a firm dedicated to MSV, raise problems that are ethically distinct from those of everyday life? The bulk of ethics teaching in business schools is narrowly Aristotelian and makes no attempt to define contemporary business's special challenges. Yet business is marked by a never-ending succession of ethical disasters - VW defeat devices, Wells Fargo sales behaviors, stock buy-backs, Deepwater Horizon, etc. Despite Donham's aggressive lead, fueled by his involvement with Chester Barnard, the author of Functions of the Executive (1938) and covered in Episode 12, and the efforts of the AACSB, business ethics remains of marginal interest to students at HBS and elsewhere. Yet it is notable that business school students cheat more than others. Not offering them relevant guidance, can management educators claim that the students' huge 'educational opportunity cost' is socially beneficial, especially in the face of the trend to privatize the cost of, and the falling value of, attending business school and the savage privatization of student debt? There is reason to fear the MBA has replaced the bachelor degree as the required minimum certification for career employment, even as those hiring care little about the syllabi studied. Because business education is likely to be the lowest-cost highestrevenue activity in the university the institutional dilemmas are especially severe. Business schools and their prodigious fundraising have done much to commercialize and corporatize universities at every level, a transformation led by same elite universities the public might most expect to resist what many see as the corruption of their Humboldtian or Newmanesque charters. Today's business school deans seldom provide much educational leadership, being judged more on their performance as fund raisers. Consequently, they are forced into earning their keep (McDonald estimates Nohria's salary at over $\$ 600,000$ p.a. handily supplemented by his Tata board membership). The typical dean's time in office is dropping fast. Inasmuch as universities are in trouble, through dancing to corporate finance's tune, the business school faculty may have facilitated and 
accelerated the decline. For the most part the universities' non-business faculty members "hold their noses" and welcome the riches. At the same time, few business school professors appear to have acquired the management skills necessary to be asked to run their universities (see Episode 61). Yet, as TGP shows, despite limited institutional or national political experience, they are often ready to argue that universities and/or nations should be 'corporatized', run like businesses.

\section{VI - What is to be done?}

In full disclosure, this reviewer had many conversations with McDonald while he was preparing TGP and is generously thanked, along with Henry Mintzberg, Casey Gerald, and Ralph Nader. But this is McDonald's book. He wisely resists drawing 'actionable conclusions'. As with the best journalists, McDonald's chosen role is to reveal, to speak truth to power, bigotry, dissembling and hypocrisy, to provide facts and analysis that can support others' policy and decision-making. In TGP's epilogue he suggests business schools might try to educate into more than MSV and stop denying the political nature of private business activity and ignoring its human and ecological externalities. Private business's greed and technological prowess can indeed destroy the planet. The good news, he suggests, is that the student body world-wide is becoming more "activist", pushing administrators to provide courses more relevant to the parlous employment future they face, with automation, off-shoring, international trade, and other pressures transforming modern work, both blue-collar and professional.
But history is slithery stuff; historians must make assumptions that set up its stories though these also shape its conclusions. Both Khurana and McDonald presume an original state of virtue and tell their stories as a "fall from grace". This sets up another story of humility, redemption, and recovery. All around the world business school deans are talking about their schools' social and pedagogical responsibilities, pushing back against MSV and purely quantitative analyses, emphasizing "business ethics" and the social and environmental 'externalities' of profit-making. The times demand such posturing. Few note the absurdity of doing this without a viable theory of the private firm, a lack being forced into the public consciousness by rising social and economic inequity and Piketty's work. Should we have firms at all?

Despite the differences between business schools noted earlier, few translate such differences into the curriculum. To the contrary, MBA syllabi around the world remain amazingly homogenous in all respects save that of the use of the case method, and even in that respect the differences are diminishing, cases increasingly used to illustrate academics' theories rather than push the student to "making managerial judgments', the pseudo-activity Mintzberg has long pilloried. Business education is becoming more commodified. Schools differ mostly in the architecture of their glittering temples and in the business and social networks they help their graduates enter; not in what they teach. While Khurana pointed a finger at the AACSB and other accrediting agencies for allowing the schools to decline, McDonald says the business schools got exactly what they deserved when business journalists, not 
academics, created the "rankings". Market forces finally penetrated the management education industry; business schools lost control of their "product". But the broader story is about the industry's vaulting claim to educate young people into managerial effectiveness, going well beyond the postWW2 colonizing claim that US management education was supreme. As Mintzberg \& Lampel's research showed, there is no empirical evidence that business schools can influence business practice, for better or worse, save enabling firms to outsource their recruitment processes at the students' or the public's expense.

Analyzing the state of management education generally, and HBS in particular, cannot get far until it unshackles itself from the emasculating belief about some golden past when the enterprise was honest and uncorrupted. There never was such a time; it is a self-serving "origin myth". For any that care to look into its history, management education does not begin with founding HBS, or even with founding the Wharton School in 1881. The earliest management education we know about, given its origins may be Chinese and lost in the mists of time, were probably the schools set up by Alexander the Great to train administrators for his newly conquered Empire. Management education was always a "servant to power". There are notable parallels to the educational innovations of the Jesuit movement.

Much about management education today dates to the Cameralist schools in $18^{\text {th }}$ Century Germany and to the administrative professionalization taking place in France under Colbert that led to the Hautes Écoles. In the superbly researched yet wry The Disordered Police State: German
Cameralism in Science and Practice (2009) Andre Wakefield argues the Cameralist 'science of administration' was little more than a publicity project, a 'front' to the ugly process of extracting taxes from the populace. Management was presented as 'rational' and 'objective', masking its political nature, concealing the exercise of capitalist power. Though business schools pay little attention to the politics of the private sector almost everyone in our industry senses something of this truth. The private sector is obviously a political milieu. Apart from Singapore, the US has evolved the most business-friendly political system. For good reason President Coolidge argued in 1925 that "The chief business of the American people is business", ironically just a few years before the Great Depression and the people's realization that other things mattered too. Business is a mode of politics. Only the most naive and dogmatic can hold fast to the idea of an a-political science of business in the face of two centuries of evident failure to produce it.

The post- $19^{\text {th }}$ Century phases of US management education reflected German and French ideas. In Episode 1 McDonald tells how, with a PhD from Germany and the academic behind the Wharton School and, later, the Booth School, Edmund James was sent Paris and elsewhere by the American Bankers Association in 1891. He eventually submitted a remarkably readable 200+ page report on the state and practices of management education throughout Europe. His Education of Business Men in Europe (1893) was widely circulated within the US banking community and local communities were urged to establish business schools. Anyone interested had a well-established 
bench-mark. One thought was that more managers were needed if US industry was to expand. But another was Realpolitik that post-1871 - unification Germany made surprisingly rapid industrial, scientific, technological, and military advances even as it lacked the abundant resources the US had at its disposal. Many guessed the explanation lay in Germany's superior scientific, technological, and administrative education system. They concluded the US needed more of the same if it was to confront Germany globally, given the containment policies of the Monroe doctrine - hence the ABA's interest and action.

James's report intersected with the business education being promoted by business interests in Illinois. Around 1850, led by the anti-slavery ex-missionary Jonathan Baldwin Turner, a group of mid-Western businessmen established The Industrial League. It was not intended to bring Cameralism to America. Rather its focus was on propagating recent improvements in machine design and in agriculture, especially in fertilizers. One of the League's first victories followed congressional lobbying for the Morrill Act of 1862. This established the Land Grant universities - "for farmers and mechanics". After the Hatch Act of 1887 the Land Grant universities were funded to set up agricultural experiment stations. Eventually there were over 70 such colleges, including Cornell University and MIT. James's initiative also intersected with management thinking coming from West Point. Unlike today, the US was comparatively peaceful. Many West Point graduates were underemployed fighting and transitioned into helping manage the rapidly growing US rail system. They approached the task with military thinking, drawing on datacollection and mechanical science.

At the same time America's industrial and scientific revolutions were under way. The US university system, previously purposed to produce clerics, was "secularizing" and beginning to engage the practical and non-religious aspects of life. But the Calvinist sense that business had to balance profit-seeking with service to the community showed America's religiosity. US management education contrived a double masking of capitalist power - both rational and religious. With this in place the universities justified expansion into new areas of the socioeconomy. They had already learned how to use political connections to ensure doctors could not practice without a university degree, so shutting down a vigorous industry of "unaccredited" medical schools; engineering schools followed. Similar "professional management" qualifications were never institutionalized perhaps the real project being the MBA or the UK "chartered manager". Using their intellectual aura alone the universities successfully captured the growing industry of management education from the large number of unaccredited 'proprietary' schools such as the Mayhew Business Colleges, and Eastman, and Bryant \& Stratton Schools.

Joseph Wharton was a leading member of the Industrial League long before he helped found the Wharton School in 1881 (he also helped found Swarthmore in 1864). Wharton's pitch to the University of Pennsylvania (which he had recently saved from bankruptcy) was that management's future lay in rationality and science. He was a 
highly successful metallurgist who had been much impressed with Cameralist institutions and practices while visiting Germany on business. His Wharton School was an explicitly political project, intended to train young men into resisting the prevailing 'free-trade' politics that would have eroded Wharton's nickel and steel monopolies.

The rising $19^{\text {th }}$ century American belief in rationality also led to "pragmatism", the philosophical approach that is probably closest to management. By the end of the $19^{\text {th }}$ century most university teachers presumed business management, like economics and psychology, could be rational and a-political - potentially underpinning a profession. Despite there being no evidence of a workable science of administration, rationalist ideology implied a very specific politics. This got a major boost after WW2, repurposed as political defense against Communist ideology. On the one hand, the Marshall Plan provided complementary funds to support and mold European management education, resisted only in Germany. On the other, the Ford and Carnegie Foundations commissioned reports, published in 1959 , that revealed the un-rigorous state of US management education. The reports justified channeling substantial funding to a select group of US schools. It cajoled them into teaching and using the rigorous methods that had proven so important to the successful conduct of WW2. HBS secured the lion's share of these monies (Episode 26). Overall, the Foundation Reports displaced story-telling 'seasoned executives' with young methodologically pure academics who, at best, had limited experience of private business, let alone of managing.

\section{VII - Concluding Comment}

In short, TGP highlights the management education industry's continuing puzzle, which is to explain its stunning and unforecasted expansion despite business schools' self-serving turn to "rigorous research" and the continued non-appearance of a managerially-usable science. Why do firms hire MBAs? This is another of those curious self-regarding questions business schools might well have researched but, unaccountably, have chosen not to. TGP touches on these, a few suggestions here and there. McDonald wonders why Harvard Presidents other than Bok seldom asked "what the hell HBS was doing" especially as it has become the tail that is beginning to wag the dog. McDonald surmises HBS is becoming the center of Harvard University's international image, geography, and finances (p. 574). It will not be long before the dean of HBS is the de-facto president of the university, at which point HBS either spins itself out to maximize private profits or takes over the university.

Obviously HBS succeeds in part because Harvard succeeds, because it bobbed and weaved to advantage through bad times and good, because it has staggeringly powerful alumni pressured to donate funds and hire its graduates, but especially because its "products" have never been tested in a competitive market. In the end HBS's success may have surprisingly little to do with its administrators, especially those after Donham and Doriot. Its business and fame is contingent on the continuing success of the global management education industry. As one of this industry's leading schools, even if markedly less influential than before its moral decline in the 1980s, 
it is being carried along by the tidal wave of demand. Right now, there is little existential anxiety among HBS's professors or administrators. Their test will come when the market falters or goes into reverse. Any dean should be able to "succeed" when demand is as strong under critiqued as it is today and so many alums can be hit up to donate - whatever shortcomings commentators such as McDonald, Mintzberg, Broughton, or Pfeffer might reveal. Whether business school deans know much about managing will be revealed; as Warren Buffett quipped, "when the tide goes out you discover who has been swimming naked". TGP does not give HBS's alums, professoriate, or students much cover. Yes, McDonald agrees that HBS is as fine a business school as one might hope for; but its theoretical, pedagogical, and institutional underpinnings are wobbly at best. This will not change until it can explain what private firms are, why they exist, what their managers do, or why private sector business schools exist.

J.-C. SPENDER Kozminski University, Poland, Rutgers University, USA 
